\title{
ELECTRODEPOSITION OF Pd NANOWIRES AND NANORODS ON CARBON NANOPARTICLES *
}

\author{
Stoyan Bliznakov ${ }^{1}$, Miomir Vukmirovic ${ }^{1}$, Eli Sutter $^{2}$, Radoslav Adzic $^{1 *}$ \\ ${ }^{1}$ Chemistry Department, Brookhaven National Laboratory, Upton, NY 11973 \\ ${ }^{2}$ Center for Functional Nanomaterials, \\ Brookhaven National Laboratory, Upton, NY 11973 \\ adzic@bnl.gov
}

\begin{abstract}
We report on the method for synthesizing palladium nanowires and nanorods involving the electrodeposition on oxidized amorphous carbon nanoparticles from chloride containing solutions. The effect of the deposition overpotential and the concentration of palladium ions on the morphology of the Pd electrodeposits have been established. Palladium grows predominately in the shape of nanowires if electrodeposited at potentials in the H underpotential deposition potential (UPD) range, where chloride ions are adsorbed only at the edges of nucleated monolayer-thick clusters on the carbon surface. The effect of the concentration of palladium ions on deposits' morphology is also discussed. The mechanism of electrodeposition of Pd nanowires and nanorods in the H UPD potential range has been proposed.
\end{abstract}

Key words: Pd electrodeposition on carbon; Pd nanowires; Pd nanorods; surfactant-mediated 1D growth; Pt monolayer electrocatalysts

\section{ЕЛЕКТРОДЕПОЗИЦИЈА НА НАНОЖИЧКИ И НАНОСТАПЧИЫА НА Рd ВРЗ ЈАГЛЕРОДНИ НАНОЧЕСТИЧКИ*}

Истражуван е методот на синтеза на наножички на $\mathrm{Pd}$ и наностапчиња по пат на електродепозиција врз оксидирани аморфни јаглеродни наночестички во хлоридни раствори. Беше утврдено влијанието на пренапонот на електродепозицијата и концентрацијата на паладиумовите јони врз морфологијата на паладиумовите електродепозити. $\mathrm{Pd}$ претежно расте во форма на наножички доколку депозицијата се изведува при потенцијали понегативни од рамнотежниот потенцијал за издвојување на водородот (H UPD), при што хлоридните јони се атсорбираат само врз рабовите на моноатомскиот кластер нуклеиран врз јаглеродната површина. Исто така, испитано е и влијанието на концентрацијата на паладиумовите јони врз морфологијата на депозитот. Предложен е механизам на електродепозиција на наножички и наностапчиња на Pd во подрачјето на потенцијали на H UPD.

Клучни зборови: електродепозиција na Pd врз јаглерод; наножички на $\mathrm{Pd}$; наностапчиња на $\mathrm{Pd}$; следење на еднодимензионален пораст врз површината; монослојни Pt- електрокатализатори. 


\section{INTRODUCTION}

The activity and stability of nanoparticle electrocatalysts for the $\mathrm{O}_{2}$ reduction reaction (ORR) have a pronounced dependence on the particles size and shape [1]. Increasing the catalysts mass activity by decreasing nanoparticles size is limited by increased number of defect sites, lattice boundaries, and low coordination atoms that these zero-dimensional (0D) morphologies have at their surfaces. These sites are easily oxidized by forming $\mathrm{PtOH}$ in the reaction with water, which makes them inactive for the ORR [2]. Dissolution of Pt nanoparticles occurs first at these sites. Thus, they are the cause of Pt instability under fuel cell operating conditions. In addition, the local coordination affects the interaction between the Pt surface sites and the adsorbed oxygen-containing species. Therefore, nanostructures that would be devoid of low-coordination sites, other imperfections, having preferably smooth surfaces with the (111) facets $[1,2]$ are necessary for improving the catalytic properties and reducing the price. Our recent analysis indicates that such surfaces should be most suitable for the ORR $[1,2]$. These properties can be found with nanowires and nanorods, as indicated in some recent publications [1-3].

Similarly, the activity of the core-shell nanoparticles depends on the size and shape of the cores [1]. This is best exemplified by the $\mathrm{Pt}$ monolayer (ML) shell/Pd core electrocatalysts for the ORR. Pt ML type of catalysts is one of the most-promising class of electrocatalysts for the ORR because of their ultra-low Pt loading, excellent kinetics, and very good stability towards the ORR [4-7].

In order to improve further the Pd core stability, nanorods were chosen instead of nanoparticles with the aim of reduction of the number of low coordinating sites which are source of dissolution [2]. Besides that, an elimination of low coordinating sites can additionally improve the ORR activity by increasing surface fraction of atoms of the most ORR active facets $[1,2]$. In addition to these findings, Abruña and coauthors reported recently that there is a strong morphology dependence of the catalytic activity of Pd toward the ORR [8]. Based on the above considerations it could be concluded that smooth, defect-free, atomically flat $\mathrm{Pd}$ surfaces with low number of low-coordinated cites would be an excellent support for Pt monolayer catalysts for the ORR. This conclusion along with the ultralow Pt loading in the Pt ML shell Pd nanorods/ nanowires - core catalysts, render them as an excellent candidate for practical catalysts for the ORR in the PEMFC.

One way to generate 1-D nanostructures of metals is to confine their growth within templates, such as alumina, polycarbonate membranes, mesoporous silica, and similar media [9]. Although a template-directed synthesis is simple and straightforward, it yields polycrystalline nanostructures, and the template needs to be removed in the postsynthesis step. These disadvantages defined the method as impractical for processing of $\mathrm{Pd}$ nanorods and wires as cores for advanced $\mathrm{Pt}$ ML shell electrocatalysts [9].

The shape controlled synthesis of $\mathrm{Pd}$ nanostructures by chemical reduction of $\mathrm{Pd}$ precursor (typically $\mathrm{Na}_{2} \mathrm{PdCl}_{4}$, or $\mathrm{PdCl}_{2}$ ) by poly(vinil pyrollidone) or/and ethylene glycol in presenence of bromide, iodide or citrate ions as a capping agent have been well studied [9-11]. It is reported that by fine-tuning of the experimental conditions a highly anisotropic $\mathrm{Pd}$ nanostructures, single-crystal nanobars and nanorods can be selectively generated. The importance of both the crystallinity of the nucleated clusters and the growth rates of different crystallographic facets for the shape of the resultant nanostructure has been outlined. Furthermore, bromide adsorption, oxidative etching, and reduction kinetics are recognized as the three key factors responsible for the formation of Pd nanostructures. Unfortunately, removing of the surfactants from the Pd metallic surface after synthesis is a very difficult process, 
and hinders the applicability of the method for processing of $\mathrm{Pd}$ nanorods for catalytic applications.

The precise control of the amount and morphology of the deposits along with avoiding the use of surfactants are important advantages defining the electrodeposition as an advanced method for processing of electrocatalysts for the ORR. The initial stages of Pd electrodeposition from $\mathrm{PdCl}_{2}$ and $\mathrm{PdSO}_{4}$ containing solutions on $\mathrm{Au}$ and $\mathrm{Pt}$ single crystalline electrodes are well studied [12-17]. Generally it is known that $\mathrm{Pd}$ electrodeposition from chloride free solution is highly irreversible, and Pd grows in 3D fashion, leading to a Stranski-Krastanov growth mode, while in presence of chloride the $\mathrm{Pd}$ growth is a more layer-by-layer type $[12,13,16,18]$. To the best of our knowledge the impact of the deposition parameters on the morphology of the $\mathrm{Pd}$ electrodeposits on an oxidized carbon has not been studied in the literature up to now. In addition, although Naohara, et al. [16] reported that the $\mathrm{Pd}$ deposition mechanism is changed in the H UPD range, they did not suggest any alternative mechanism.

In the present work Pd is electrochemically deposited on thin film high-surface area oxidized carbon, supported on glassy carbon electrode. The surface of oxidized carbon is covered by functional groups that increased the sorption ability of the carbon [19] and improved the nucleation on it. The optimal conditions for electrodeposition of $\mathrm{Pd}$ nanowires, nanorods and nanoparticles have been identified. The mechanism of the growth of one dimensional nanostructure in the hydrogen UPD potential range is proposed.

\section{EXPERIMENTAL}

The general procedure for Pd deposition that was used herein included electrodeposition of Pd at constant potential on thin film oxidized carbon, supported on well polished glassy carbon (GC) electrode. A commercially available $5 \mathrm{~mm}$ in diameter GC electrode, embedded in Teflon ${ }^{\circledR}$ holder (Pine Instruments) was polished to a mirror finish and cleaned. A thin film of oxidized carbon (Cabot, Vulcan 72R) was cast on the GC surface. An oxidized carbon was chosen in order to increase the nucleation density during the deposition process. Procedures for carbon oxidizing are described elsewhere [19]. Briefly, predetermined amount of carbon was immersed in concentrated nitric acid for 24 hours at room temperature. After rinsing and drying, $10 \mathrm{mg}$ of carbon was dispersed in $10 \mathrm{ml}$ nanopure water by sonication in ultrasound bath for at least 30 minutes. $5 \mu 1$ droplet of as prepared suspension was cast on the glassy carbon surface and was slowly dried at room temperature. This procedure was repeated several times until the electrode surface was completely covered by thin film of homogenously distributed oxidized carbon. After activation by potential cycling, the electrodeposition of Pd was carried out. All the potentials were measured against standard $\mathrm{Ag} / \mathrm{AgCl} / \mathrm{NaCl}$ (3M, BAS Inc.) reference electrode, and were quoted with respect to reversible hydrogen electrode (RHE). Pure argon gas (Praxair, 4.8 grade) was purged for at least 30 minutes through the electrolyte in order to deoxygenate it. All electrochemical tests were conducted on Biologic VSP potentiostat/ galvanostat, controlled by EC-Lab V10.02 software.

The electrochemical deposition was performed potentiostatically in $0.1 \mathrm{M} \mathrm{NaCl}$ (Sigma Aldrich, $99.999 \%$ ) solution containing $\mathrm{PdCl}_{2}$ (SigmaAldrich, 99.9\%), the concentration of which was varied in the range of $0.05 \mathrm{mM}$ to $0.8 \mathrm{mM}$. The amount of deposited Pd was controlled coulometrically. For each sample the charge was fixed at $10 \mathrm{mC}$ that corresponded about $28 \mu \mathrm{g} / \mathrm{cm}^{2}$.

The particles size and the catalysts morphology were characterized by transmission electron microscopy (TEM). For the TEM observation the catalyst layer was peeled off from the GC electrode surface via sonication in $1 \mathrm{ml}$ of ethanol. Then $30 \mu 1$ from the suspension 
was cast drop by drop on a TEM grid (Ted Pella, Inc.). As prepared samples were characterized using JOEL2100F TEM, operated at $200 \mathrm{kV}$.

\section{RESULTS AND DISCUSSION}

\subsection{Electrochemistry of palladium deposition on oxidized carbon}

Figure 1 shows a characteristic cyclic voltammetry $(\mathrm{CV})$ curves for thin film oxidized carbon, supported on GC electrode, in deaerated $0.1 \mathrm{M} \mathrm{NaCl}+0.8 \mathrm{mM} \mathrm{PdCl}_{2}$ solution, recorded at scan rate of $10 \mathrm{mV} / \mathrm{s}$ with, and without rotation. The kinetics of the Pd electroreduction is improved as a result of the electrode rotation, and the amount of deposited Pd increases. There are three pairs of asymmetric cathodic/anodic peaks observed at potentials more positive than the onset potential for hydrogen evolution/oxidation. The first pair of narrow peaks at about $0.01-0.06 \mathrm{~V}$, see Figure 1 inset, is attributed to H UPD adsorption/desorption on Pd. The broad pair of peaks at about $0.14-0.2 \mathrm{~V}$ is due to either H UPD or chloride ion adsorption/desorption $[12,20,21]$. The most asymmetric couple of cathodic/anodic peaks at $0.45-0.85 \mathrm{~V}$ is assigned to $\mathrm{Pd}$ deposition/dissolution, respectively. The negative shift of all the peaks discussed above and their asymmetry are associated with the strong adsorption of both chloride ions and tetrachloropalladate complex existing in the electrolyte on the Pd surface [13, 20-22]. The cathodic peak at about $0.45 \mathrm{~V}$ corresponds to $\mathrm{Pd}$ reduction from the tetrachloropalladate $\left(\left[\mathrm{PdCl}_{4}\right]^{2-}\right)$ complex [13]. This is a dominated complex in the solution of interest [13]. The onset potential for $\mathrm{Pd}$ deposition is at about $0.5 \mathrm{~V}$ in both cases. As the inset of Figure 1 shows, after passing the maximum at about $0.45 \mathrm{~V}$ the cathodic current reaches the limiting diffusion current densities to a planar electrode and remains constant up to about $0.2 \mathrm{~V}$. The diffusion of $\left[\mathrm{PdCl}_{4}\right]^{2-}$ complex to the electrode surface is improved upon rotation of the electrode and no cathodic peak for Pd reduction is observed in the CV curve. It is seen that after initial rapid increase the current density approaches slowly its limiting diffusion values at the specific rotation speed.

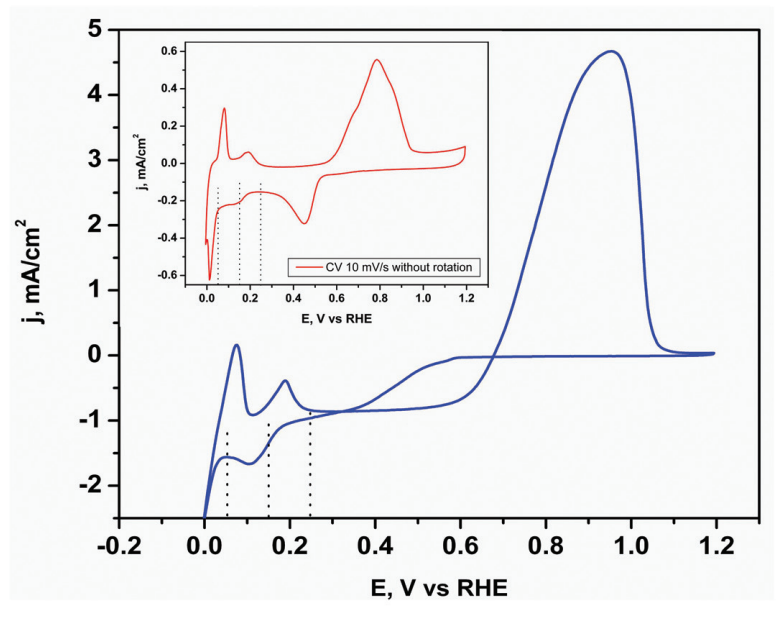

Fig. 1. CV curves measured for thin film oxidized carbon on GC electrode at scan rate $10 \mathrm{mV} / \mathrm{s}$ in $0.1 \mathrm{M}$ $\mathrm{NaCl}+0.8 \mathrm{mM} \mathrm{PdCl}_{2}$ solution at rotation rate of 1600 $\mathrm{rpm}$ and without rotation (inset)

It is well known that tetrachloropalladate complex plays an important role in Pd electrodeposition/dissolution on $\mathrm{Pt}$ and $\mathrm{Au}$ single crystal electrodes $[13,16]$. The $\left[\mathrm{PdCl}_{4}\right]^{2-}$ ions are adsorbed on the single crystal $\mathrm{Au}$ (111) facets, and form densely packed layer in the potential range between $0.66 \mathrm{~V}$ and $1.2 \mathrm{~V}$ vs. RHE [17, 23]. Also, it was found that a complete pseudomorphic monolayer of $\mathrm{Pd}$ in the UPD range was formed on the $\mathrm{Pt}(111)$ and $\mathrm{Au}$ (111) electrodes in chloride containing solutions [13]. It was reported that a distorted hexagonal adlayer of Pd chloro- complex is formed also on Pd deposited on $\mathrm{Au}$ or $\mathrm{Pt}(111)$ surface, and that the $\mathrm{Pd}$ growth continue in layer-bylayer fashion [13]. In addition, Naohara, et al. [16] confirmed that the adsorbed $\left[\mathrm{PdCl}_{4}\right]^{2-}$ complex inhibits the three-dimensional growth and facilitates the two-dimensional growth of $\mathrm{Pd}$ on $\mathrm{Au}(111)$. In our case the Pd deposition begins at potentials more negative than the equilibrium potential for bulk Pd deposition on Pt (111) electrode [12]. The negative potential shift is attributed to either existence of the 
overpotential for Pd bulk deposition on carbon or absence of ordered adlayer of the $\left[\mathrm{PdCl}_{4}\right]^{2-}$ ions on the carbon surface. We assume that as a result of an increased nucleation density on the oxidized carbon surface and the electrolyte composition the $\mathrm{Pd}$ deposition begins with formation of monatomically thin clusters. The two-dimensional nucleation of Pd is suggested from the potentiostatic current transients and is discussed later in the paper. Immediately after nucleation, the surface of the clusters is covered by specifically adsorbed chloride ions that are more strongly adsorbed on the Pd surface than the $\left[\mathrm{PdCl}_{4}\right]^{2-}$ ions in the potentials more negative than $0.66 \mathrm{~V}$ [13]. The mechanism for $\mathrm{Pd}$ electroreduction from $\left[\mathrm{PdCl}_{4}\right]^{2-}$ on $\mathrm{Pd}$ in presence of chloride ions is identical to the Pt electroreduction from $\left[\mathrm{PtCl}_{4}\right]^{2-}$ on $\mathrm{Pt}$ as suggested by Kravtsov [24]. We propose the mechanism realized in three stages. The first stage yields an adsorbed complex in which the bond between the bridging $\mathrm{Cl}^{-}$with the central $\mathrm{Pd}(\mathrm{II})$ is weaker than that in the initial $\left[\mathrm{PdCl}_{4}\right]^{2-}$ complex. In the second stage a bond between the central ion of Pd complex and surface Pd atoms is formed. The third stage is an electrochemical and involves a multi-stepped or almost simultaneous transfer of two electrons [24].

As mentioned above, the broad peak at about $0.14 \mathrm{~V}$ is in the hydrogen UPD region, and is due to either H UPD adsorption or chloride ions desorption [23]. The sharp cathodic peak that is close to $0.0 \mathrm{~V}$, see Figure 1 inset, corresponds to H UPD adsorption on bare Pd surface [21]. According to Naohara et al. [16], the $\mathrm{Pd}$ deposition proceeds steadily in the H UPD range, although the electrode surface is free from adsorbed $\left[\mathrm{PdCl}_{4}\right]^{2-}$ ions. The mechanism for Pd electrodeposition in the H UPD potential range has not been proposed so far.

\subsection{Factors affecting the Pd morphology and the growth of one-dimensional Pd nanostructures in the HUPD range}

Five Pd deposits were obtained at different constant potentials in the range indicated in Figure 1. A current-time transient for the $\mathrm{Pd}$ electrodeposition at $0.05 \mathrm{~V}$ in deaerated $0.1 \mathrm{M}$ $\mathrm{NaCl}+0.8 \mathrm{mM} \mathrm{PdCl}_{2}$ solution, and at rotation rate of $1600 \mathrm{rpm}$, is presented in Figure 2. In addition the corresponding chronocoulometric curve is presented in the same figure. It was observed that the charge increased linearly with the time after the limited current density was reached, and the amount of deposited Pd was limited to $10 \mathrm{mC}$ for all samples. The shape of the chronoamperometric curve suggests an instantaneous 2D nucleation with planar diffusion growth control $[25,26]$. The shape of the curve does not depend on the deposition overpotential, and similar transients are registered for all samples studied in the present work. It was found that such shape is attributed to the faster nucleation on oxidized carbon surfaces [25].

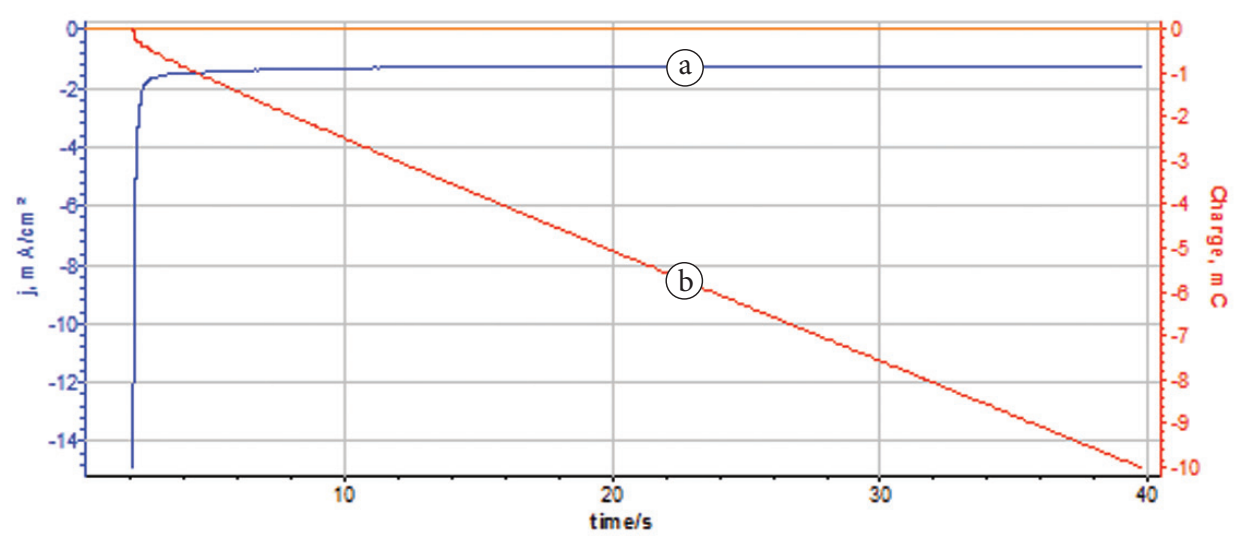

Fig. 2. Current time transient acquired on a thin film oxidized carbon on $\mathrm{GC}$ electrode in $0.8 \mathrm{mM} \mathrm{PdCl}+0.1 \mathrm{M} \mathrm{NaCl}$ solution at rotation speed of $1600 \mathrm{rpm}$ at deposition overpotential of $0.5 \mathrm{~V}$ (a).

Line (b) shows the respective charge-time transient.

Maced. J. Chem. Chem. Eng. 30 (1), 19-27 (2011) 


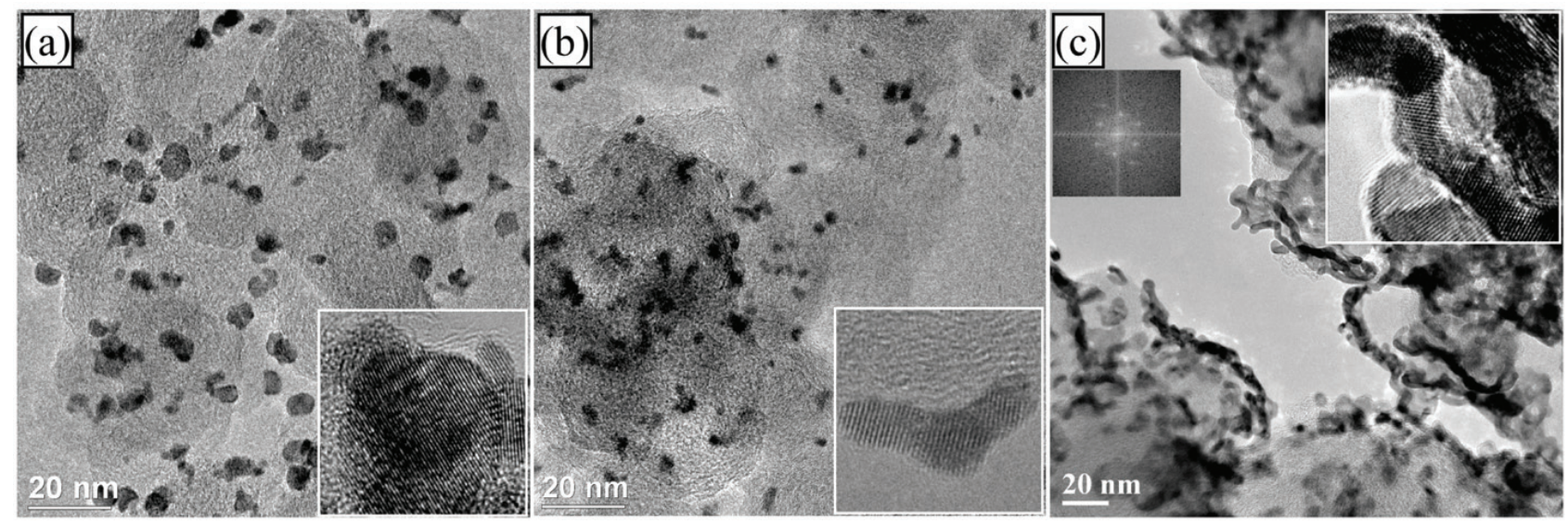

Fig. 3. TEM images of electrodeposited Pd nanostructures at different overpotentials: a) at $0.25 \mathrm{~V}$; b) at $0.1 \mathrm{~V}$, and c) at $0.05 \mathrm{~V}$. The HRTEM images of nanoparticles, nanorods and nanowires are presented as insets. The second inset in (c) shows the fast fourier transform (fft) pattern of selected area from the nanowires.

A very interesting dependence of the morphology of the Pd deposits from the deposition potential in the H UPD range is seen from Figure 3, where the TEM images for as deposited samples at three different overpotentials are presented. Generally, it is seen that the shape of the Pd nanostructures is changed from nanoparticles to nanorods and to nanowires with increasing of the deposition overpotential. The mechanism of instantaneous nucleation suggests that nuclei are created simultaneously, their number remains constant and their growth rate is the same. Consequently, the change into the growth mechanism could be the only reason for as observed morphology change.

The nanoparticles from Figure $3 \mathrm{a}$ with irregular shape and narrow size distribution of about $5 \mathrm{~nm}$ are deposited at $0.25 \mathrm{~V}$. This potential is still not in the H UPD range and the $\mathrm{Pd}$ deposition proceeds by reduction of tetrachloropalladate complex linked to the adsorbed layer of chloride ions on as nucleated $\mathrm{Pd}$ two-dimensional clusters, following the mechanism stages discussed above. Obviously, this growth mode results in deposition of $\mathrm{Pd}$ nanoparticles. The second sample is deposited at potential of $0.1 \mathrm{~V}$ that is in the H UPD range. It is seen from the TEM image shown in Figure $3 b$ that $\mathrm{Pd}$ nanorods with aspect ratio of $4-5$ are formed substantially in addition to some nanoparticles. The TEM image presented in
Figure $3 \mathrm{c}$ is for the sample deposited at $0.05 \mathrm{~V}$. It is seen that at this potential Pd is predominantly deposited as nanowires with diameter of $4 \mathrm{~nm}$ and length of $50-60 \mathrm{~nm}$, distributed mainly on the edges of the amorphous carbon particles. This is the first evidence for an electrodeposition of Pd nanowires on carbon nanoparticles.

The high-resolution transmission electron microscopy (HRTEM) images of the samples are presented as insets in the Figure 3. It is seen that all deposited $\mathrm{Pd}$ nanostructures are single crystalline. Lattice fringes with interplanar spacing of $0.22 \mathrm{~nm}$, ascribed to (111) planes of the face-centered cubic (fcc) structure of $\mathrm{Pd}$, are clearly seen in the HRTEM images. The $\mathrm{fft}$ pattern of selected area from the single nanowire, shown as inset in Figure 3c, indicate that most of the Pd atoms are ordered in (111) facets. It also confirms that the surface fraction of Pd atoms on the (111) facets is predominant in the sample of interest.

At potentials below $0.2 \mathrm{~V}$ two processes occur in parallel at a Pd surface: chloride desorption and H UPD adsorption. It is likely that as the chloride desorption begins from the surface of nucleated two-dimensional clusters (facets), simultaneously H UPD adsorption takes place on the chloride-free Pd atoms. Thus, the chloride ion coverage on the cluster surface decreases, while the hydrogen atoms coverage increases gradually at more negative potentials. 


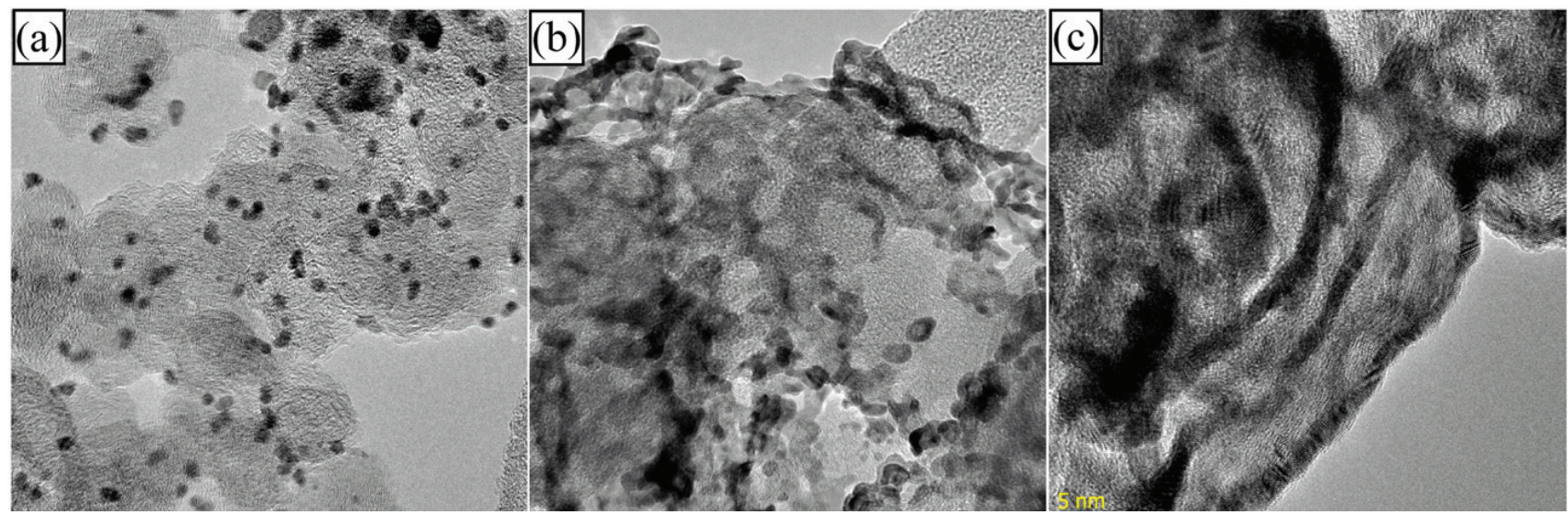

Fig. 4. TEM images of $\mathrm{Pd}$ deposits from $0.1 \mathrm{M} \mathrm{NaCl}$ solution with different concentrations of the $\mathrm{PdCl}_{2}$ : a) $0.08 \mathrm{mM}$; b) $0.1 \mathrm{mM}$; c) $0.8 \mathrm{mM}$.

The chloride ions adsorbed on the edges of the Pd clusters are the most strongly adsorbed, and they can be completely desorbed at about 0.04 $\mathrm{V}$. Hence, at about $0.05 \mathrm{~V}$ there are chloride ions specifically adsorbed only on the edges of the Pd clusters, while the facets are partially covered by UPD adsorbed hydrogen atoms. In this scheme the adsorbed hydrogen on the Pd surface reduces $\mathrm{Pd}$ complex and promotes a layer-by-layer growth of Pd, similarly as in the $\mathrm{Pb}$ UPD-mediated two-dimensional growth of $\mathrm{Ag}$ on $\mathrm{Ag}(111)$ [27]. This method facilitates an electrochemical surfactant-mediated layer-bylayer metal growth. The hydrogen UPD layer on Pd surface enhances the nucleation density [16] as an ideal surfactant, since its high mobility [28] makes it "floating" on the Pd surface as growth proceeds.

According to the above mechanism, at $0.05 \mathrm{~V}$ Pd grows in a layer-by-layer fashion in the direction normal to the electrode surface. As the edges of the clusters at this potential are blocked by specifically adsorbed chloride ions, the lateral growth is hindered, and $\mathrm{Pd}$ grows in shape of nanowires, as is shown in Figure 3c. In addition, the diameter of the nanowires is defined by the size of the nucleated clusters, and their length depends on the amount of deposited $\mathrm{Pd}$. As the $\mathrm{H}$ underpotential deposition and $\left[\mathrm{PdCl}_{4}\right]^{2-}$ complex decomposition are very fast processes $[24,28]$ the growth kinetics of the nanowires is very fast. When the deposition is performed between $0.05 \mathrm{~V}$ and $0.2 \mathrm{~V}$ both deposition mechanisms are operating. As a result, the H UPD coverage is not sufficiently high and the surfactant mediated growth mode is not efficient enough to grow nanowires. That is why nanoparticles or mixtures of nanoparticles and nanorods are observed in the TEM image in Figure $3 b$. If most of the clusters' surface is chloride-free, but the $\mathrm{H}$ coverage is low, the growth proceeds in $3 \mathrm{D}$ mode almost immediately after the nucleation [27], and results in formation of nanorods.

The Pd ion concentration in the solution affects the morphology of the deposits. For the concentration of $\mathrm{Pd}^{2+} 0.1 \mathrm{mM}$ and higher $\mathrm{Pd}$ grows as nanowire (Figure 4). In addition, the length of the nanowires increases with increasing of the $\mathrm{Pd}^{2+}$ concentration. This observation is in good agreement with the conclusion for the diffusion limited growth control of the $\mathrm{Pd}$ deposits. The nanowires are distributed mainly on the edges of the carbon particles. According to the proposed mechanism for Pd deposition in the H UPD range, the two-dimensional growth of the nanowires is in direction normal to the electrode surface. Most probably they are redistributed to the carbon edges as a result of the sonication procedure that is used for the sample preparation for the TEM imaging. 


\section{CONCLUSIONS}

Paladium nanorods and nanowires can be deposited electrochemically on carbon nanoparticles. The deposition parameters affect the morphology of electrodeposited Pd nanostructures. The morphology of the Pd nanostructures can be controlled by tuning up the deposition overpotential and the concentration of $\mathrm{Pd}$ in the solution. The conditions at which Pd predominately grows in shape of nanowires, nanorods and nanoparticles have been identified. If the deposition is performed at potentials more positive than the onset potential for the chloride ions desorption, $\mathrm{Pd}$ is deposited in shape of nanoparticles. If the deposition is performed at potentials just before the onset potential for H UPD adsorption on bare Pd surface, where the chloride ions are specifically adsorbed only on the edges of the clusters the Pd is predominately deposited in shape of nanowires. In addition, if the potential for $\mathrm{Pd}$ deposition is in the mixed range, where chloride ions are not completely desorbed and the hydrogen atoms are partially UPD adsorbed on the clusters surface, $\mathrm{Pd}$ is deposited in shapes of nanoparticles and nanorods. The one-dimensional Pd nanostructures grow in the H UPD range, where the incomplete H UPD monolayer acts as a surfactant that promotes a layer-by-layer growth of Pd nanowires. The electrodeposited Pd nanowires/ nanorods are promising candidates as cores for the Pt ML- shell electrocatalysts for the ORR in fuel cell cathodes.

Acknowledgments. This work was funded by the Division of Chemical Sciences, Geosciences, and Biosciences, Office of Basic Energy Sciences of the U.S. Department of Energy through Grant DE-AC02-98CH10886.

\section{REFERENCES}

[1] J. X. Wang, H. Inada, L. J. Wu, Y. M. Zhu, Y. M. Choi, P. Liu, W. P. Zhou, R. R. Adzic, Oxygen Reduction on Well-Defined Core-Shell Nanocatalysts: Particle Size, Facet, and Pt Shell Thickness Effects, Journal of the American Chemical Society, 131 (2009), 17298-17302.

[2] C. Koenigsmann, W. P. Zhou, R. R. Adzic, E. Sutter, S. S. Wong, Size-Dependent Enhancement of Electrocatalytic Performance in Relatively DefectFree Processed Ultrathin Platinum Nanowires, Nano Letters, 10 (2010), 2806-2811.

[3] Z. W. Chen, M. Waje, W. Z. Li, Y. S. Yan, Supportless Pt and PtPd nanotubes as electrocatalysts for oxygen reduction reactions, Angewandte ChemieInternational Edition, 46 (2007), 4060-4063.

[4] J. L. Zhang, M. B. Vukmirovic, Y. Xu, M. Mavrikakis, R. R. Adzic, Controlling the catalytic activity of platinum-monolayer electrocatalysts for oxygen reduction with different substrates, Angewandte Chemie-International Edition, 44 (2005), 2132-2135.

[5] R. R. Adzic, J. Zhang, K. Sasaki, M. B. Vukmirovic, M. Shao, J. X. Wang, A. U. Nilekar, M. Mavrikakis, J. A. Valerio, F. Uribe, Platinum monolayer fuel cell electrocatalysts. Topics in $\mathrm{Ca}$ talysis, 46 (2007), 249-262.

[6] J. Zhang, Y. Mo, M. B. Vukmirovic, R. Klie, K. Sasaki, R. R. Adzic, Platinum monolayer electrocatalysts for $\mathrm{O}^{-2}$ reduction: $\mathrm{Pt}$ monolayer on $\operatorname{Pd}(111)$ and on carbon-supported Pd nanoparticles, Journal of Physical Chemistry B, 108 (2004), 10955-10964.

[7] A. U. Nilekar, Y. Xu, J. L. Zhang, M. B. Vukmirovic, K. Sasaki, R. R. Adzic, M. Mavrikakis, Bimetallic and ternary alloys for improved oxygen reduction catalysis, Topics in Catalysis, 46 (2007), 276-284.

[8] L. Xiao, L. Zhuang, Y. Liu, J. T. Lu, H. D. Abruna, Activating Pd by Morphology Tailoring for Oxygen Reduction, Journal of the American Chemical Society, 131 (2009), 602-608.

[9] Y. J. Xiong, H. G. Cai, B. J. Wiley, J. G. Wang, M. J. Kim, Y. N. Xia, Synthesis and mechanistic study of palladium nanobars and nanorods, Journal of the American Chemical Society, 129 (2007), 3665-3675. 
[10] Y. J. Xiong, Y. N. Xia, Shape-controlled synthesis of metal nanostructures: The case of palladium, Advanced Materials, 19 (2007) 3385-3391.

[11] X. Q. Huang, N. F. Zheng, High-Yield Synthesis of 5-Fold Twinned Pd Nanowires and Nanorods, Journal of the American Chemical Society, 131 (2009), 4602.

[12] R. Hoyer, L. A. Kibler, D. M. Kolb, The initial stages of palladium deposition onto $\mathrm{Pt}(111)$, Electrochimica Acta, 49 (2003), 63-72.

[13] L. A. Kibler, M. Kleinert, R. Randler, D. M. Kolb, Initial stages of Pd deposition on $\mathrm{Au}(\mathrm{hkl})$ - Part I: Pd on Au(111), Surface Science, 443 (1999), 19-30.

[14] L. A. Kibler, M. Kleinert, V. Lazarescu, D. M. Kolb, Initial stages of palladium deposition on Au(hkl) - Part III: Pd on Au(110), Surface Science, 498 (2002), 175-185.

[15] L.A. Kibler, M. Kleinert, D.M. Kolb, Initial stages of Pd deposition on Au(hkl). - Part II: Pd on Au(100), Surface Science, 461 (2000), 155-167.

[16] H. Naohara, S. Ye, K. Uosaki, Electrochemical deposition of palladium on an $\mathrm{Au}(111)$ electrode: Effects of adsorbed hydrogen for a growth mode, Colloids and Surfaces a. Physicochemical and Engineering Aspects, 154 (1999), 201-208.

[17] H. Naohara, S. Ye, K. Uosaki, Electrochemical layer-by-layer growth of palladium on an $\mathrm{Au}(111)$ electrode surface: Evidence for important role of adsorbed Pd complex, Journal of Physical Chemistry B, 102 (1998), 4366-4373.

[18] M. J. Ball, C. A. Lucas, N. M. Markovic, V. Stamenkovic, P. N. Ross, From sub-monolayer to multilayer - an in situ X-ray diffraction study of the growth of Pd films on Pt(111), Surface Science, 518 (2002), 201-209.

[19] I. I. Salame, T. J. Bandosz, Study of water adsorption on activated carbons with different degrees of surface oxidation, Journal of Colloid and Interface Science, 210 (1999), 367-374.

[20] T. J. Schmidt, N. M. Markovic, V. Stamenkovic, P. N. Ross, G. A. Attard, D. J. Watson, Surface characterization and electrochemical behavior of well-defined Pt-Pd $\{111\}$ single-crystal surfaces: A comparative study using Pt $\{111\}$ and palladium-modified Pt $\{111\}$ electrodes, Langmuir, 18 (2002), 6969-6975.

[21] M. Arenz, V. Stamenkovic, T. J. Schmidt, K. Wandelt, P. N. Ross, N. M. Markovic, The effect of specific chloride adsorption on the electrochemical behavior of ultrathin Pd films deposited on Pt(111) in acid solution, Surface Science, 523 (2003), 199209.

[22] I. A. Pasti, S. V. Mentus, Halogen adsorption on crystallographic (111) planes of $\mathrm{Pt}, \mathrm{Pd}, \mathrm{Cu}$ and $\mathrm{Au}$, and on Pd-monolayer catalyst surfaces: Firstprinciples study, Electrochimica Acta, 55 (2010), 1995-2003.

[23] A. M. El-Aziz, L. A. Kibler, D. M. Kolb, The potentials of zero charge of $\mathrm{Pd}(111)$ and thin Pd overlayers on Au(111), Electrochemistry Communications, 4 (2002), 535-539.

[24] V. I. Kravtsov, Platinum Electrodeposition mechanism during the reduction of platinum chloride complexes, Russian Journal of Electrochemistry, 36 (2000), 1209-1215.

[25] N. Massoni, A. Beaumont-Martinent, J. Y. Laurent, Effect of an oxygen plasma treatment on the specific surface of platinum electrodeposits for fuel cells, Journal of Power Sources, 166 (2007), 68-73.

[26] B. Scharifker, G. Hills, Theoretical and experimental studies of multiple nucleation, Electrochimica Acta, 28 (1983), 879-889.

[27] S. R. Brankovic, N. Dimitrov, K. Sieradzki, Surfactant mediated electrochemical deposition of Ag on $\mathrm{Au}(111)$, Electrochemical and Solid State Letters, 2 (1999), 443-445.

[28] G. Jerkiewicz, Electrochemical Hydrogen adsorption and absorption. Part 1: Under-potential deposition of hydrogen, Electrocatalysis, 1 (2010), 179-199. 
